\title{
Sex Difference in Plasma Deoxyribonuclease Activity in Rats
}

\section{Lubica JANOVIČOVÁ ${ }^{1}$, Barbora GROMOVÁ ${ }^{1}$, Diana DROBNÁ ${ }^{1}$, Barbora KONEČNÁ ${ }^{\mathbf{1}}$, Emese RENCZÉS ${ }^{1}$, Veronika BORBÉLYOVÁ ${ }^{1}$, Július HODOSY ${ }^{1,2}$, Peter CELEC ${ }^{1,3,4}$}

${ }^{1}$ Institute of Molecular Biomedicine, Faculty of Medicine, Comenius University, Bratislava, Slovakia, ${ }^{2}$ Institute of Physiology, Faculty of Medicine, Comenius University, Bratislava, Slovakia, ${ }^{3}$ Institute of Pathophysiology, Faculty of Medicine, Comenius University, Bratislava, Slovakia, ${ }^{4}$ Department of Molecular Biology, Faculty of Natural Sciences, Comenius University, Bratislava, Slovakia

Received July 16, 2021

Accepted September 14, 2021

Epub Ahead of Print October 30, 2021

\section{Summary}

Extracellular DNA (ecDNA) activates immune cells and is involved in the pathogenesis of diseases associated with inflammation such as sepsis, rheumatoid arthritis or metabolic syndrome. DNA can be cleaved by deoxyribonucleases (DNases), some of which are secreted out of cells. The aim of this experiment was to describe plasma DNase activity in relation to extracellular DNA in adult rats, to analyse potential sex differences and to prove whether they are related to endogenous testosterone. Adult Lewis rats $(n=28)$ of both sexes were included in the experiment. Male rats were gonadectomized or sham-operated and compared to intact female rats. Plasma ecDNA and DNase activity were measured using fluorometry and single radial enzyme diffusion assay, respectively. Concentrations of nuclear ecDNA and mitochondrial ecDNA were determined using real-time PCR. Females had $60 \%$ higher plasma DNase activity than males $(p=0.03)$. Gonadectomy did not affect plasma DNase aktivity in males. Neither the concentration of total ecDNA, nor nuclear or mitochondrial DNA in plasma differed between the groups. No significant correlations between DNase aktivity and ecDNA were found. From previous studies on mice, it was expected, that male rats will have higher DNase activity. In contrast, our study in rats showed the opposite sex difference. This sex difference seems not to be caused by endogenous testosterone. Interestingly, no sex differences were observed in plasma ecDNA suggesting a complex or missing association between plasma ecDNA and DNase. The observed sex difference in plasma DNase aktivity should be taken into account in animal models of ecDNAassociated diseases.

\section{Key words}

Cell-free DNA • Nuclease activity • NETosis • Experimental rodents

\section{Corresponding author}

Peter Celec, Institute of Molecular Biomedicine, Faculty of Medicine, Comenius University, Bratislava, Slovakia. E-mail: petercelec@gmail.com

\section{Introduction}

Extracellular DNA (ecDNA) is a term covering all DNA molecules outside of cells. Intracellular nucleic acids can be released from cells during apoptosis or necrosis (Stroun et al. 2001). A characteristic feature of ecDNA is the specific pattern of fragmentation. The average fragment length is approximately $166 \mathrm{bp}$. It is thought to represent the length of a single turn of DNA wrapped around histones (Chandrananda et al. 2015). EcDNA can originate from nucleus or mitochondria and both can cause an activation of immune cells via Toll-like receptor 9 signalisation, but also other DNA sensors (Speranskii et al. 2016).

Deoxyribonucleases (DNases) are enzymes which can cleave DNA. Activity of these enzymes depends on their expression and, thus, quantity, but also on the presence of activators and inhibitors such as divalent ions of calcium and magnesium or actin, respectively. DNase I is secreted outside of cells, where it can cleave ecDNA. In animal models of diseases such as ischemic-reperfusion injury, liver failure, sepsis and colitis, exogenous DNase I helps to prevent tissue damage and improves survival (Mai et al. 2015, Albadawi et al. 2016, Vokalova et al. 2017, Babickova et al. 2018). The positive effects of DNase I 
administration are likely mediated by the cleavage of the DNA mesh in neutrophil extracellular traps preventing further inflammation and coagulation (Delgado-Rizo et al. 2017). Sex differences in disease severity were described in a model of liver failure with male rats having a worse prognosis (Koblihova et al. 2020). Understanding these differences and the underlying mechanisms potentially involving DNase is crucial when selecting a disease model, model organism and translating the results to humans.

Sex differences were identified in DNase activity in some tissues in mice but not yet in rats (Koizumi 1995). There are several possible explanations why there are sex differences in DNase activity. Sex hormones may be responsible for the regulation of DNase production or activity. Body composition might be responsible for sex differences in ecDNA or DNase activity. The higher body fat has a partial association with higher ecDNA concentration (Camuzi Zovico et al. 2020). The reason might be the sex difference in ecDNA removal. Sex differences were observed in brain damage and subsequent behavioral impairments in both, mice, and rats (Lastuvka et al. 2020, Riljak et al. 2020). The causes and consequences of these sex differences are unknown. As ecDNA is involved in the pathogenesis of autoimmune diseases, sepsis and other pathologies, sex differences in ecDNA or DNase could be of importance for the understanding of sex differences in disease risk in humans or variability in disease models in experimental animals. Therefore, our aim was to describe plasma DNase activity and ecDNA concentration in plasma of adult male and female rats. In addition, using castration we wanted to prove whether the expected sex differences are due to the action of androgens.

\section{Methods}

\section{Animals and procedures}

The experiment was approved by the local Ethics Committee of the Institute of Molecular Biomedicine. All experiments were performed in accordance with the national legislation. All surgery was performed under ketamine: xylazine anaesthesia cocktail and all efforts were made to minimize suffering. Twentyeight healthy adult Lewis rats (Anlab, Prague, Czech Republic) of both sexes were included in experimental procedures and were housed under standard condition with stable temperature, 12/12-hour light/dark cycle and ad libitum access to standard pellet diet (KMK20, EYPY,
Czech republic) and water. The animals were divided into 3 groups: control males which were sham-operated, gonadectomized males and control females. Rats were gonadectomized or sham operated on postnatal day 29-31. At the age of 18 months blood was collected into both, EDTA- and heparin-containing tubes from the aorta in ketamine: xylazine anaesthesia. Blood was centrifuged at $2000 \mathrm{~g}$ for $5 \mathrm{~min}$. EDTA plasma was centrifuged again to remove cell debris at $16000 \mathrm{~g}$ for $10 \mathrm{~min}$ at $4{ }^{\circ} \mathrm{C}$. The supernatant of plasma samples was stored at $-20{ }^{\circ} \mathrm{C}$ until analysis.

\section{Testosterone measurement}

Testosterone concentration in plasma was measured using a commercially available ELISA kit (DRG Diagnostic, Marburg, Germany) to confirm the effect of castration. Measurement was carried out according to the standard protocol provided by the manufacturer.

\section{DNase activity measurement}

DNase activity was measured in heparin plasma using the modified single radial enzyme diffusion assay. Briefly, agarose gels were prepared with final concentration of solutes: $1 \mathrm{mM} \mathrm{CaCl}_{2}, 1 \mathrm{mM} \mathrm{MgCl}$ and DNA isolated from rat liver $(0.5 \mathrm{mg} / \mathrm{ml})$. Ethidium bromide was replaced with the fluorescent dye Goodview (SBS Genetech, Beijing, China). DNase activity was recalculated based on serial dilutions of RNase-free DNase I (Qiagen, Hilden, Germany). After 18 hours of incubation, gels were scanned using iBOX (Vision works LP Analysis Software, UVP, Upland, CA, USA). Diameters of cleared circles on the gel were measured using ImageJ software.

\section{Quantification of extracellular DNA}

EDTA plasma was used for the isolation of ecDNA using the QIAamp DNA Blood Mini kit (Qiagen, Hilden, Germany). Concentration of ecDNA was measured using a fluorometric method with the Qubit 3.0 fluorometer and Qubit dsDNA HS kit (Thermo Fisher Scientific, Waltham, MA, USA). Quantification of DNA using real-time PCR was conducted for both, nuclear and mitochondrial DNA. Real-time PCR was performed on the Mastercycler realplex 4 (Eppendorf, Hamburg, Germany). The reaction was carried out with $7.5 \mu \mathrm{l}$ of SYBR Green master mix (Qiagen, Hilden, Germany), $0.3 \mu \mathrm{l}$ of forward primer $(10 \mu \mathrm{M}), 0.3 \mu \mathrm{l}$ of reverse primer $(10 \mu \mathrm{M}), 3.9 \mu \mathrm{l}$ of millipore water and $3 \mu \mathrm{l}$ of 
template. For nuclear DNA (ncDNA) forward 5'- GAAATCCCCTGGAGCTCTGT -3' and reverse 5'- CTGGCACCAGATGAAATGTG -3' primers (GADPH) (Hu et al. 2015), for mitochondrial DNA (mtDNA) forward- 5'-CCT CCC ATT CAT TAT CGC CGC CCT TGC-3' and reverse 5'-GTC TGG GTC TCC TAG TAG GTC TGG GAA-3' primers (211 bp mitochondria fragment) (Rooney et al. 2015) (Eurofins Genomics, Ebersberg, Germany) were used. The PCR program consisted of initial DNA denaturation at $95^{\circ} \mathrm{C}$ for $15 \mathrm{~min}, 40$ cycles of denaturation at $94^{\circ} \mathrm{C}$ for $15 \mathrm{sec}$, annealing at $60{ }^{\circ} \mathrm{C}$ for $30 \mathrm{sec}$ and elongation at $72{ }^{\circ} \mathrm{C}$ for $30 \mathrm{sec}$ followed by melting curve analysis to confirm specificity of the PCR. Analysis of distribution of ecDNA fragments length of selected samples from males and castrated males was done using capillary electrophoresis and the BIABooster technology (Adelis, Grabels, France) (Andriamanampisoa et al. 2018).

\section{Statistics}

Data were analysed using GraphPad Prism 6 (La Jolla, CA, USA). Comparison of groups was carried out using ANOVA with Bonferroni corrected t-test. Correlation analysis was conducted with the Pearson correlation test. P-values less than 5\% were considered significant. Results are presented as mean + standard deviation.

\section{Results}

Plasma testosterone was $0.85+0.24 \mathrm{nmol} / 1$ in females and in $4.71+2.95 \mathrm{nmol} / 1$ males $(\mathrm{t}=6.76, \mathrm{p}<0.001)$ confirming the physiological sex difference. Males after castration had testosterone concentrations of $0.68+0.18 \mathrm{nmol} / 1$ which is significantly lower in comparison to control males $(\mathrm{t}=6.72, \mathrm{p}<0.001)$ and similar to females.

A sex difference in DNase activity was found in plasma. Female rats had on average $60 \%$ higher DNase activity compared to control male rats. There was no difference in DNase activity between control males and castrated males $(\mathrm{F}=3.87, \mathrm{p}=0.03$; females vs males $\mathrm{t}=2.66$ $\mathrm{p}=0.03$, males vs castrated males $\mathrm{t}=0.31 \mathrm{p}>0.99$ ) (Fig. 1A).
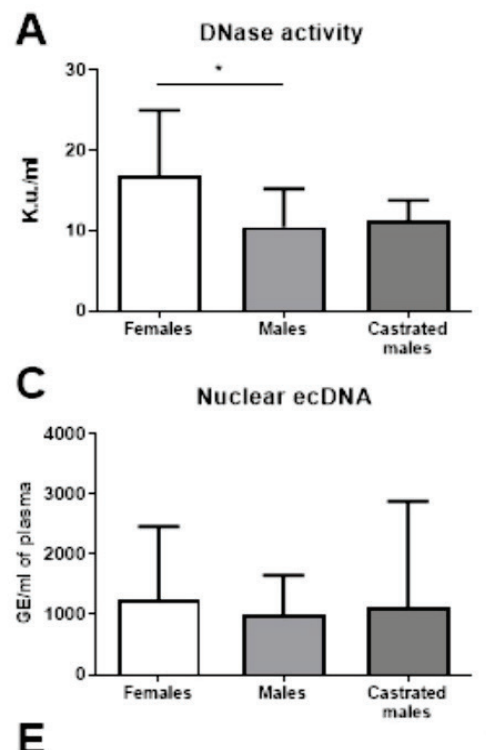

\section{E}

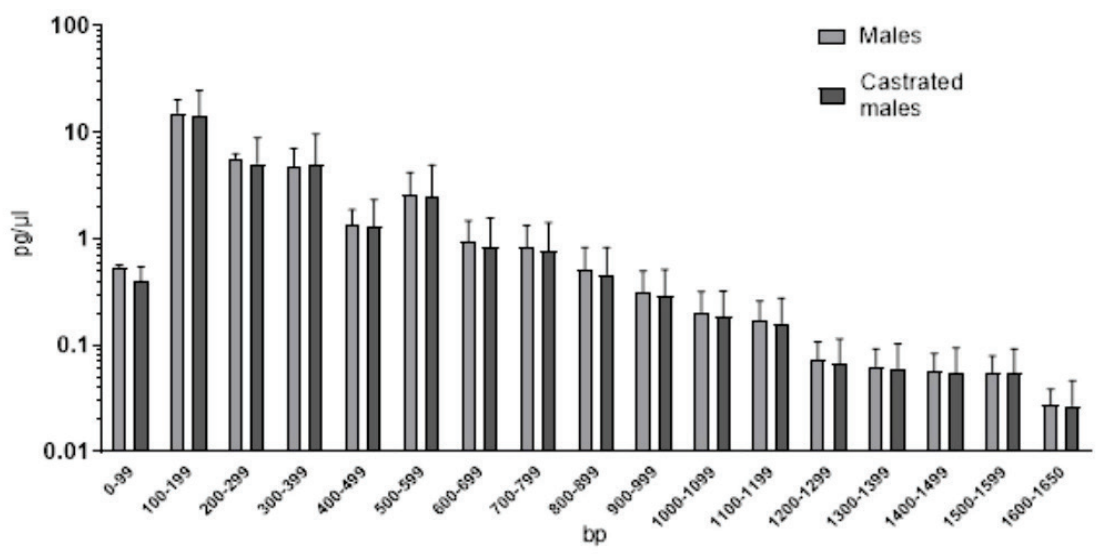

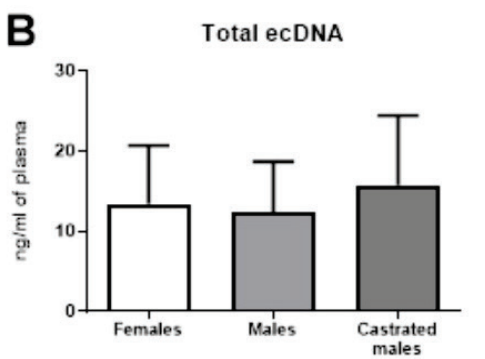

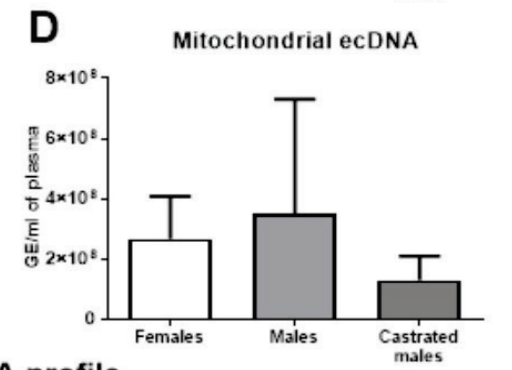

ecDNA profile

(D) mtDNA between groups. (E) Analysis of ecDNA profile of the distribution of DNA fragment lengths. No difference was observed in the length distribution of DNA fragments between males and castrated males. The results are shown as mean + standard deviation. 
A

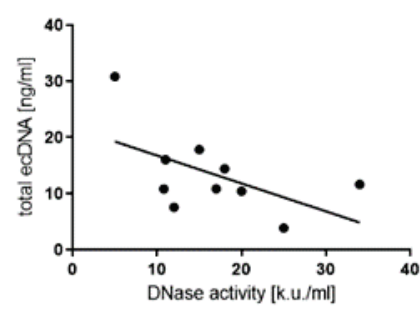

D

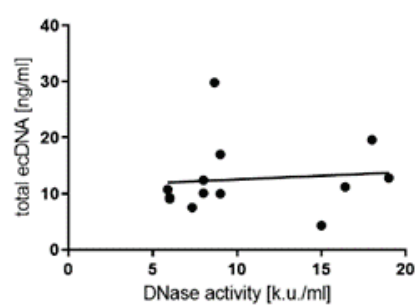

G

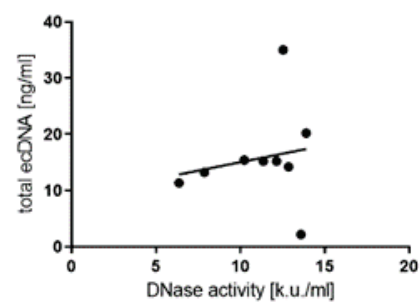

B

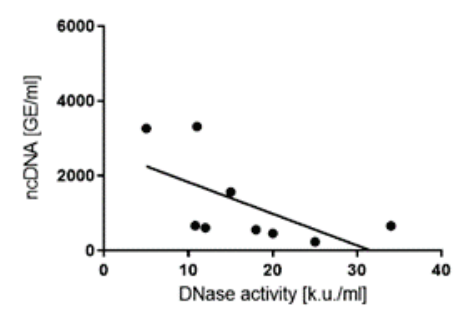

E

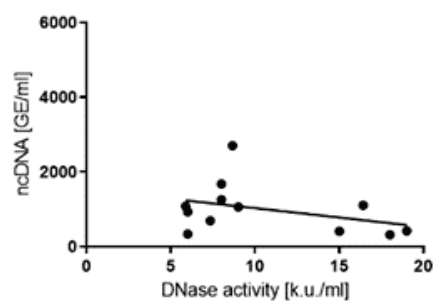

H

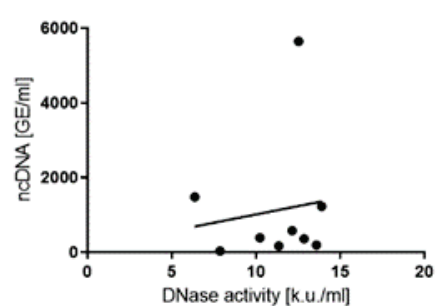

C

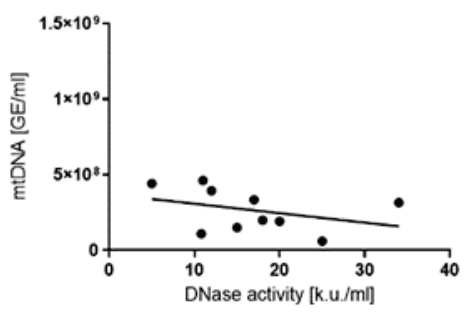

F

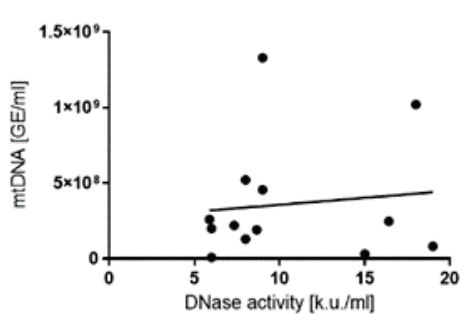

I

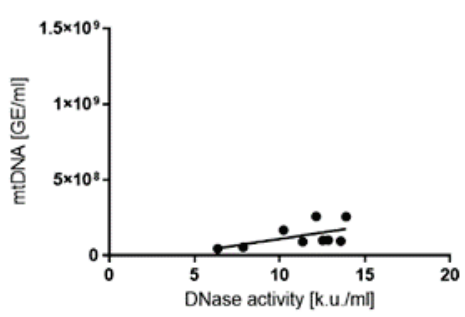

Fig. 2. Correlation of DNase activity with total ecDNA, ncDNA and mtDNA. No statistically significant correlations were found in any of the experimental groups. In females, no correlation of DNase with (A) ecDNA, (B) ncDNA and (C) mtDNA was observed. In control males, no correlation of DNase with (D) ecDNA (F), mtDNA and (E) ncDNA was observed. Similarly, in castrated males, no significant correlation of DNase activity with (G) ecDNA, (H) ncDNA and (I) mtDNA was found.

Concentration of total plasma ecDNA was measured in castrated males, control males and control females. No differences between groups were observed in concentrations of total ecDNA $(\mathrm{F}=0.57, \mathrm{p}=0.57)$ (Fig. 1B). Quantification of ecDNA by PCR also showed no sex difference. Groups did not differ in plasma ncDNA $(\mathrm{F}=0.12, \mathrm{p}=0.89)$ or mtDNA $(\mathrm{F}=1.90, \mathrm{p}=0.17)$ (Fig. 1C,D). High interindividual variability was observed in both, ncDNA (CV: $107 \%$ ) and mtDNA (CV: $103 \%$ ). Fragmentation analysis of ecDNA showed no difference in ecDNA size profile between males and castrated males. In both groups the highest peak was around 100-200 bp length with similar distribution of DNA fragments between the groups (Interaction: $\mathrm{F}=0.02$, $\mathrm{p}>0.99$; Fragment length: $\mathrm{F}=15.01, \mathrm{p}<0.001$; Groups: $\mathrm{F}=0.06 ; \mathrm{p}=0.81$, Fig. 1E).

No significant correlation of DNase activity with total ecDNA in plasma was found $(r=-0.56, p=0.09$, Fig. 2A). Similarly, no correlations of DNase activity and
ncDNA ( $r=-0.61, p=0.08$, Fig. $2 \mathrm{~B})$ or $\mathrm{mtDNA}$ were found $(r=-0.36, p=0.31$, Fig. $2 C)$. In male rats, concentration of ecDNA and DNase activity did not correlate $(\mathrm{r}=0.10$, $\mathrm{p}=0.75$, Fig. 2D). No association was found for DNase activity and mtDNA ( $r=0.11, p=0.72$, Fig. $2 E)$ or ncDNA in male rats $(r=-0.37, p=0.24$, Fig. $2 F)$. DNase activity did not correlate with ecDNA in castrated male rats $(\mathrm{r}=0.18, \mathrm{p}=0.64$, Fig. $2 \mathrm{G})$. A correlation was not observed between DNase activity and neither ncDNA ( $\mathrm{r}=0.13$, $\mathrm{p}=0.74$, Fig. $2 \mathrm{H})$ nor mtDNA in castrated males $(\mathrm{r}=0.55$, $\mathrm{p}=0.13$, Fig. 2I).

\section{Discussion}

In our study, we have found a sex difference in plasma DNase activity in rats. Surprisingly, female rats had higher DNase activity compared to male rats. The opposite sex difference was expected based on the study where higher DNase activity was observed in liver, 
kidney and urine from male mice (Koizumi 1995). It is clear that there are major interspecies differences in DNase activity in plasma (Konecna et al. 2018). The origin of plasma DNase activity should be understood before further animal experiments testing the effects of exogenous or endogenous DNase on models of human diseases are conducted.

No differences between groups were observed in ecDNA of any subcellular origin. However, the concentrations of ecDNA, ncDNA and mtDNA showed high interindividual variability. Interestingly, no association was found between plasma DNase activity and ecDNA quantified using two different methods spectrofluorometry and PCR. This could be explained by the fact that total DNA measured spectrofluorometrically includes short fragments that are not identified using real time PCR. It is unclear whether these short fragments are of biological importance. It is expected that concentration of ecDNA in plasma can be to some degree affected by DNases. Our results show that there is no simple linear negative association between ecDNA and DNase. This could be explained by the likely protection of plasma ecDNA by nucleosomes, which might be of importance especially for ncDNA (Ljungman et al. 1992). On contrary, mtDNA does not interact with histones, but in our study mtDNA does not correlate with DNase activity either. One of recent reports suggests that plasma ecDNA could be hidden in extracellular vesicles such as exosomes, which might protect both, ncDNA and mtDNA from degradation by plasma DNase activity (Fernando et al. 2017). Whether this is true for plasma DNA of experimental animals is currently not clear.

Research of ecDNA is focusing mostly on diagnostic applications, but relatively little is known about its biology, for example the sources of variability of its concentrations in plasma. On the other hand, the quantity of plasma ecDNA is being tested as a potential disease marker e.g. in sepsis (Clementi et al. 2016). Free ecDNA outside of exosomes and free from histones and other DNA-binding proteins could be cleaved by plasma DNase. However, a single study describing the relationship between concentration of ecDNA and DNase activity showed that DNase I knock-out mice do not have altered fragmentation of ecDNA in plasma (Cheng et al. 2018). Our results confirm this finding and show that there is no linear association between ecDNA and DNase activity in mouse plasma. Recently, two DNases were shown to be essential for survival of mice in induced neutrophilia that increases ecDNA. DNase I and DNase
1L3 cooperate to manage ecDNA concentrations in the extracellular space (Jimenez-Alcazar et al. 2017). Our analysis covers the ability of plasma to cleave DNA rather than focusing on specific DNases. Other clearance mechanisms should also be considered, for example macrophages, which digest debris after cell death were shown to aid ecDNA removal (Nakazawa et al. 2016). It is possible that healthy animals have very little completely free ecDNA in plasma since no major pathological mechanisms are activated that could increase its production. This speculation requires many additional experiments especially with experimental animals suffering from a disease model such as sepsis or trauma.

Sex differences in plasma DNase activity could be caused by sex hormones modulating DNase activity. However, we have found no differences between control and castrated males, which suggests that testosterone is not the factor affecting plasma DNase activity in adult rats. So, an alternative to testosterone in males could be the effect of estrogens in females that will be tested in our future experiments. Male rat castration leads to low grade inflammation that is not affected by replacement therapy (Chin et al. 2017). A similar experiment on females with ovariectomy showed similar results (Benedusi et al. 2015). This inflammation could explain an increase in ecDNA, but neither plasma ecDNA nor DNase activity were affected by castration in our experiment. Besides sex hormones, genetic factors could underlie sex differences in plasma DNase activity. Despite inactivation of one $\mathrm{X}$ chromosome in females, gene dosage could affect DNase activity. DNase X is located on the $\mathrm{X}$ chromosome. However, this DNase is highly expressed in skeletal muscles and it is not known to affect the plasma DNase activity (Shiokawa et al. 2007). DNases were shown to be regulated by EndoG. This enzyme is secreted from mitochondria and can cleave both, DNA and RNA (Zhdanov et al. 2015). Whether EndoG regulation or its expression is sex-specific is currently unknown.

In mice and humans, males have higher DNase activity in plasma. This known sex difference is driving the interest in the research of sex differences in relation to sex hormones. Studies previously described DNase activity in many organs among which were testes, ovaries and prostate. Gonadectomy in male mice induces apoptosis in cells of prostate and increase in DNAfragmentation (Kyprianou et al. 1988). The gonadectomy is linked to muscle atrophy which is caused by autophagy. A study showed that fasting in castrated rats 
induces muscle atrophy linked to mitochondrial stress (Rossetti et al. 2018). The muscle atrophy could be a source of DNase I inhibitor, actin (Lazarides et al. 1974). Even if DNase activity was determined by sex hormones, it still could be inhibited in castrated rats, therefore, not changing the DNase activity in their plasma. The gonadectomy was described to lead to accumulation of DNase I in prostate epithelial cells. It is the DNase I or its isoforms that act to cleave ecDNA in cells preparing to undergo apoptosis (Rauch et al. 1997).

One of the limitations of our analysis is that the DNase 1L3 is inhibited by heparin in collection tubes. The choice of anticoagulant may affect the DNase activity. The blood for DNase activity measurement cannot be collected in EDTA-containing tubes as EDTA is an inhibitor of DNase I. Another option is to collect serum which is unsuitable for analysis of ecDNA because during the coagulation process ecDNA is released. If ecDNA is released so can be other co-factors or proteins altering DNase activity in plasma.

In conclusion, according to our knowledge this is the first study showing a sex difference in plasma DNase activity in rats. On contrary, plasma ecDNA of both, nuclear and mitochondrial origin, is comparable in both sexes. What are the causes for the observed sex difference remains to be studied, because castration did not affect plasma DNase activity. An opposite sex difference has been described in mice and large interspecies differences in DNase activity exist (Konecna et al. 2018). Nevertheless, from the experimental rodents, rats in contrast to mice have a DNase activity that is similar to humans. Thus, it is likely that rats rather than mice should be used to model ecDNA-associated human diseases. It is crucial to uncover the determinants of plasma DNase activity and the mechanism of the observed sex difference. This might shed light on the pathogenesis of sepsis, trauma complications, but also other pathologies. Additional studies are required to describe the regulation of plasma DNase activity and/or ecDNA concentrations. Their results might be helpful in the understanding of the pathogenesis of ecDNAassociated diseases.

\section{Conflict of Interest}

There is no conflict of interest.

\section{Acknowledgements}

The research was supported by the Slovak Research and Development Agency (APVV-16-0273).

\section{References}

ALBADAWI H, OKLU R, RAACKE MALLEY RE, O'KEEFE RM, UONG TP, CORMIER NR, WATKINS MT: Effect of DNase I treatment and neutrophil depletion on acute limb ischemia-reperfusion injury in mice. J Vasc Surg 64: 484-493, 2016. https://doi.org/10.1016/j.jvs.2015.01.031

ANDRIAMANAMPISOA CL, BANCAUD A, BOUTONNET-RODAT A, DIDELOT A, FABRE J, FINA F, GARLAN F, GARRIGOU S, GAUDY C, GINOT F, HENAFF D, LAURENT-PUIG P, MORIN A, PICOT V, SAIAS L, TALY V, TOMASINI P, ZAANAN A: BIABooster: Online DNA concentration and size profiling with a limit of detection of $10 \mathrm{fg} / \mathrm{mul}$ and application to high-sensitivity characterization of circulating cell-free DNA. Anal Chem 90: 3766-3774, 2018. https://doi.org/10.1021/acs.analchem.7b04034

BABICKOVA J, CONKA J, JANOVICOVA L, BORIS M, KONECNA B and GARDLIK R: Extracellular DNA as a prognostic and therapeutic target in mouse colitis under dnase i treatment. Folia Biol 64: 10-15, 2018.

BENEDUSI V, MARTINI E, KALLIKOURDIS M, VILLA A, MEDA C, MAGGI A: Ovariectomy shortens the life span of female mice. Oncotarget 6: 10801-10811, 2015. https://doi.org/10.18632/oncotarget.2984

CAMUZI ZOVICO PV, GASPARINI NETO VH, VENANCIO FA, SOARES MIGUEL GP, GRACA PEDROSA R, KENJI HARAGUCHI F and BARAUNA VG: Cell-free DNA as an obesity biomarker. Physiol Res 69: 515-520, 2020. https://doi.org/10.33549/physiolres. 934242

CLEMENTI A, VIRZI GM, BROCCA A, PASTORI S, DE CAL M, MARCANTE S, GRANATA A, RONCO C: The role of cell-free plasma DNA in critically ill patients with sepsis. Blood Purif 41: 34-40, 2016. https://doi.org/10.1159/000440975

DELGADO-RIZO V, MARTINEZ-GUZMAN MA, INIGUEZ-GUTIERREZ L, GARCIA-OROZCO A, ALVARADO-NAVARRO A, FAFUTIS-MORRIS M: Neutrophil extracellular traps and its implications in inflammation: an overview. Front Immunol 8: 81, 2017. https://doi.org/10.3389/fimmu.2017.00081 
FERNANDO MR, JIANG C, KRZYZANOWSKI GD, RYAN WL: New evidence that a large proportion of human blood plasma cell-free DNA is localized in exosomes. PLoS One 12: e0183915, 2017. https://doi.org/10.1371/journal.pone.0183915

HU Q, WOOD CR, CIMEN S, VENKATACHALAM AB, ALWAYN IP: Mitochondrial damage-associated molecular patterns (MTDs) are released during hepatic ischemia reperfusion and induce inflammatory responses. PLoS One 10: e0140105, 2015. https://doi.org/10.1371/journal.pone.0140105

CHANDRANANDA D, THORNE NP, BAHLO M: High-resolution characterization of sequence signatures due to non-random cleavage of cell-free DNA. BMC Med Genomics 8: 29, 2015. https://doi.org/10.1186/s12920-015$\underline{0107-z}$

CHENG THT, LUI KO, PENG XL, CHENG SH, JIANG P, CHAN KCA, CHIU RWK, LO YMD: DNase1 does not appear to play a major role in the fragmentation of plasma DNA in a knockout mouse model. Clin Chem 64: 406-408, 2018. https://doi.org/10.1373/clinchem.2017.280446

CHIN KY, IMA-NIRWANA S: The effects of testosterone deficiency and its replacement on inflammatory markers in rats: a pilot study. Int J Endocrinol Metab 15: e43053, 2017. https://doi.org/10.5812/ijem.43053

JIMENEZ-ALCAZAR M, RANGASWAMY C, PANDA R, BITTERLING J, SIMSEK YJ, LONG AT, BILYY R, KRENN V, RENNE C, RENNE T, KLUGE S, PANZER U, MIZUTA R, MANNHERZ HG, KITAMURA D, HERRMANN M, NAPIREI M, FUCHS TA: Host DNases prevent vascular occlusion by neutrophil extracellular traps. Science 358: 1202-1206, 2017. https://doi.org/10.1126/science.aam8897

KOBLIHOVA E, MRAZOVA I, VANOURKOVA Z, MAXOVA H, RYSKA M, FRONEK J: Sex-linked differences in the course of thioacetamide-induced acute liver failure in Lewis rats. Physiol Res 69: 835-845, 2020. https://doi.org/10.33549/physiolres.934499

KOIZUMI T: Tissue distribution of deoxyribonuclease I (DNase I) activity level in mice and its sexual dimorphism. Exp Anim 44: 181-185, 1995. https://doi.org/10.1538/expanim.44.181

KONECNA B, LAUKOVA L, VLKOVA B: Immune activation by nucleic acids: A role in pregnancy complications. Scand J Immunol 87: e12651, 2018. https://doi.org/10.1111/sji.12651

KONECNA B, SYSAK R, KACEROVSKY M, CELEC P and VLKOVA B: Deoxyribonuclease activity in plasma of pregnant women and experimental animals. J Matern Fetal Neonatal Med 31: 1807-1809, 2018. https://doi.org/10.1080/14767058.2017.1326899

KYPRIANOU N, ENGLISH HF, ISAACS JT: Activation of a $\mathrm{Ca}^{2+}-\mathrm{Mg}^{2+}$-dependent endonuclease as an early event in castration-induced prostatic cell death. Prostate 13: 103-117, 1988. https://doi.org/10.1002/pros.2990130203

LASTUVKA Z, BORBELYOVA V, JANISOVA K, OTAHAL J, MYSLIVECEK J, RILJAK V: Neonatal hypoxicischemic brain injury leads to sex-specific deficits in rearing and climbing in adult mice. Physiol Res 69: S499-S512, 2020. https://doi.org/10.33549/physiolres.934604

LAZARIDES E, LINDBERG U: Actin is the naturally occurring inhibitor of deoxyribonuclease I. Proc Natl Acad Sci U S A 71: 4742-4746, 1974. https://doi.org/10.1073/pnas.71.12.4742

LJUNGMAN M, HANAWALT PC: Efficient protection against oxidative DNA damage in chromatin. Mol Carcinog 5: 264-269, 1992. https://doi.org/10.1002/mc.2940050406

MAI SH, KHAN M, DWIVEDI DJ, ROSS CA, ZHOU J, GOULD TJ, GROSS PL, WEITZ JI, FOX-ROBICHAUD AE, LIAW PC, CANADIAN CRITICAL CARE TRANSLATIONAL BIOLOGY G: Delayed but not early treatment with DNase reduces organ damage and improves outcome in a murine model of sepsis. Shock 44: 166-172, 2015. https://doi.org/10.1097/SHK.0000000000000396

NAKAZAWA D, SHIDA H, KUSUNOKI Y, MIYOSHI A, NISHIO S, TOMARU U, ATSUMI T, ISHIZU A: The responses of macrophages in interaction with neutrophils that undergo NETosis. J Autoimmun 67: 19-28, 2016. https://doi.org/10.1016/j.jaut.2015.08.018

RAUCH F, POLZAR B, STEPHAN H, ZANOTTI S, PADDENBERG R, MANNHERZ HG: Androgen ablation leads to an upregulation and intranuclear accumulation of deoxyribonuclease $\mathrm{I}$ in rat prostate epithelial cells paralleling their apoptotic elimination. J Cell Biol 137: 909-923, 1997. https://doi.org/10.1083/jcb.137.4.909

RILJAK V, LASTUVKA Z, MYSLIVECEK J, BORBELYOVA V, OTAHAL J: Early postnatal hypoxia induces behavioral deficits but not morphological damage in the hippocampus in adolescent rats. Physiol Res 69: 165179, 2020. https://doi.org/10.33549/physiolres.934234 
ROONEY JP, RYDE IT, SANDERS LH, HOWLETT EH, COLTON MD, GERM KE, MAYER GD, GREENAMYRE JT, MEYER JN: PCR based determination of mitochondrial DNA copy number in multiple species. Methods Mol Biol 1241: 23-38, 2015. https://doi.org/10.1007/978-1-4939-1875-1_3

ROSSETTI ML, STEINER JL, GORDON BS: Increased mitochondrial turnover in the skeletal muscle of fasted, castrated mice is related to the magnitude of autophagy activation and muscle atrophy. Mol Cell Endocrinol 473: 178-185, 2018. https://doi.org/10.1016/j.mce.2018.01.017

SHIOKAWA D, MATSUSHITA $T$, SHIKA $Y$, SHIMIZU M, MAEDA M, TANUMA S: DNase $X$ is a glycosylphosphatidylinositol-anchored membrane enzyme that provides a barrier to endocytosis-mediated transfer of a foreign gene. J Biol Chem 282: 17132-17140, 2007. https://doi.org/10.1074/jbc.M610428200

SPERANSKII AI, KOSTYUK SV, KALASHNIKOVA EA, VEIKO NN: Enrichment of extracellular DNA from the cultivation medium of human peripheral blood mononuclears with genomic $\mathrm{CpG}$ rich fragments results in increased cell production of IL-6 and TNF-a via activation of the NF-kB signaling pathway. Biomed Khim 62: 331-340, 2016. https://doi.org/10.18097/PBMC20166203331

STROUN M, LYAUTEY J, LEDERREY C, OLSON-SAND A, ANKER P: About the possible origin and mechanism of circulating DNA apoptosis and active DNA release. Clin Chim Acta 313: 139-142, 2001. https://doi.org/10.1016/S0009-8981(01)00665-9

VOKALOVA L, LAUKOVA L, CONKA J, MELISKOVA V, BORBELYOVA V, BABICKOVA J, TOTHOVA L, HODOSY J, VLKOVA B, CELEC P: Deoxyribonuclease partially ameliorates thioacetamide-induced hepatorenal injury. Am J Physiol Gastrointest Liver Physiol 312: G457-G463, 2017. https://doi.org/10.1152/ajpgi.00446.2016

ZHDANOV DD, FAHMI T, WANG X, APOSTOLOV EO, SOKOLOV NN, JAVADOV S, BASNAKIAN AG: Regulation of apoptotic endonucleases by EndoG. DNA Cell Biol 34: 316-326, 2015. https://doi.org/10.1089/dna.2014.2772 